\title{
Effects of polychlorinated biphenyl (Aroclor 1254) on steroidogenesis and antioxidant system in cultured adult rat Leydig cells
}

\author{
Palaniappan Murugesan, Muthusamy Balaganesh, Karundevi Balasubramanian and \\ Jagadeesan Arunakaran \\ Department of Endocrinology, Dr ALM Post Graduate Institute of Basic Medical Sciences, University of Madras, Taramani Campus, Chennai 600113 , India \\ (Requests for offprints should be addressed to J Arunakaran; Email: j_arunakaran@hotmail.com) \\ (P Murugesan is now at Department of Obstetrics and Gynecology, University of Michigan Medical School, Ann Arbor, Michigan 48109, USA)
}

\begin{abstract}
Polychlorinated biphenyls (PCBs) are ubiquitous and persistent environmental contaminants that disturb normal endocrine functions, including gonadal functions in humans and mammals. In the present study, we examined the direct effects of PCB on rat Leydig cells in vitro. Adult Leydig cells were purified by Percoll gradient centrifugation method and the purity of Leydig cells was also determined by $3 \beta$-hydroxysteroid dehydrogenase $(3 \beta-\mathrm{HSD})$ staining method. Purified Leydig cells were exposed to different concentrations $\left(10^{-10}-10^{-7} \mathrm{M}\right)$ of PCB (Aroclor 1254) for $24 \mathrm{~h}$ under basal and LH-stimulated conditions. After the experimental period, cultured media were collected and used for the assay of testosterone and estradiol. The treated cells were used for the quantification of cell-surface LH receptors and activities of steroidogenic enzymes, such as cytochrome $\mathrm{P}_{450}$ side-chain cleavage enzyme $\left(\mathrm{P}_{450} \mathrm{scc}\right), 3 \beta-$ HSD, and 17 $\beta$-hydroxysteroid dehydrogenase (17 $\beta$-HSD). Leydig cellular enzymatic antioxidants, such as superoxide dismutase, catalase, glutathione peroxidase, glutathione reductase, $\gamma$-glutamyl transpeptidase, glutathione- $S$-transferase, and nonenzymatic antioxidants, such as vitamins $\mathrm{C}$ and $\mathrm{E}$, were assayed. Lipid peroxidation (LPO) and reactive oxygen species
\end{abstract}

(ROS) were also estimated in Leydig cells. In addition, total RNA was isolated from control and Aroclor 1254-exposed Leydig cells to monitor the steady-state mRNA levels by reverse transcription(RT)-PCR for steroidogenic acuteregulatory (StAR) protein, cytochrome $\mathrm{P}_{450} \mathrm{scc}, 3 \beta-\mathrm{HSD}$, and $17 \beta-$ HSD. Our results indicated that Aroclor $1254\left(10^{-9}\right.$, $10^{-8}$, and $10^{-7} \mathrm{M}$ ) treatments significantly inhibit basal and LH-stimulated testosterone and estradiol production. In addition, the activities of steroidogenic enzymes, enzymatic and nonenzymatic antioxidants were significantly diminished in a dose-dependent manner. However, LPO and ROS were elevated in a dose-dependent manner under basal and LH-stimulated conditions. RT-PCR analysis of StAR mRNA level showed a decrease only in $10^{-7} \mathrm{M}$ dose of Aroclor 1254 treatment, while cytochrome $\mathrm{P}_{450} \mathrm{scc}, 3 \beta-\mathrm{HSD}$, and $17 \beta-H S D$ mRNAs were drastically decreased in both $10^{-8}$ and $10^{-7} \mathrm{M}$ Aroclor 1254 treatment. These findings suggest that PCBs can act directly on Leydig cells to diminish testosterone production by inhibiting gene expression of steroidogenic enzymes and antioxidant system.

Journal of Endocrinology (2007) 192, 325-338

\section{Introduction}

It is well known that environmental pollutants disrupting endocrine and reproductive functions in wild animals, experimental animals, and humans still occur widely (Bruss et al. 2004, Vidaeff \& Sever 2005). Polychlorinated biphenyls (PCBs) are worldwide environmental pollutants and have caused adverse effects on the male reproductive system. The persistence and ubiquitous distribution of these compounds cause them to remain potentially serious hazards to human and animal health (Kimbrough 1995). In addition, PCBs are strongly lipophilic and highly stable compounds. Aroclors are a commercial mixture of PCBs, which are usually given a four-digit number, of which the first two digits refer to the number of carbon atoms attached to the biphenyl ring and the last two indicate the percentage of chlorine (Nessel \& Gallo
1994). It is believed that the toxic effects of PCBs are primarily mediated through their ability to bind to the aryl hydrocarbon receptor (AhR) with high affinity (Safe 1995). The AhR is a ligand-activated transcription factor that, upon binding of PCBs or dioxin, translocates to the nucleus where it heterodimerizes with the aryl hydrocarbon nuclear translocator. This complex then binds to xenobiotic response elements or dioxin-responsive elements located in the regulatory regions of certain genes or interferes with various signal molecules in the cells (Safe 1995, Massaad et al. 2002).

Exposure to PCBs has been associated with defects in spermatogenesis as well as reduced weight of testis and accessory sex organs in adult rats (Gray et al. 1993, Murugesan et al. 2005a). In rhesus monkeys, exposure to PCBs resulted in reduced sperm counts and decreased cellular contents in the seminiferous tubules (Ahmad et al. 2003). In human, the levels 
of PCBs have been inversely correlated to the sperm number and motility (Rozati et al. 2002). In contrast, neonatal exposure to PCBs has been reported to cause enlarged testis and increased testicular sperm counts that may possibly be associated with Sertoli cell changes (Cooke et al. 1996). Leydig cells are present in the interstitial compartment of the testis and their main function is to produce testosterone which is essential for spermatogenesis and development of secondary sexual characteristics. Luteinizing hormone $(\mathrm{LH})$ is the primary regulator of Leydig cell function (Habert et al. 2001). A continuous exposure of lactating mothers to Aroclor 1242 causes significant effects on Leydig cell structure and function, hypotrophy, and reduced capacity to produce testosterone in vitro in response to $\mathrm{LH}$ stimulation (Kim et al. 2001). Recent studies from our laboratory have demonstrated that adult rats exposed to PCBs disrupt Sertoli and Leydig cellular functions in adult rats (Senthil kumar et al. 2004, Krishnamoorthy et al. 2005, Murugesan et al. 2005b,c). The cultured Leydig cells from adult rats that were exposed to PCBs resulted in lowered synthesis of testosterone following human chorionic gonadotropin stimulation (Kovacevic et al. 1995). LH secreted from the anterior pituitary gland regulates testosterone biosynthesis in testicular Leydig cells. LH secretion is regulated by gonadotropin-releasing hormone released from the hypothalamus. Previous studies from our laboratory demonstrated that PCB altered the hypothalamicpituitary-testicular axis in adult rats (Murugesan et al. 2005c, Muthuvel et al. 2006).

In Leydig cell steroidogenesis, the substrate cholesterol is converted into testosterone through a series of steroidogenic steps catalyzed by different enzymes (Payne \& Hales 2004). The delivery of free cholesterol to the inner mitochondrial membrane is required to initiate the steroidogenic process. This is the rate-limiting step of steroidogenesis and is mediated by the steroidogenic acute-regulatory (StAR) protein (Clark et al. 1994). The first enzymatic step in steroidogenesis is the cholesterol being converted to pregnenolone by cytochrome $\mathrm{P}_{450} \mathrm{scc}$ (Payne \& Hales 2004). We have previously demonstrated that the steroidogenic enzymes, such as $\mathrm{P}_{450} \mathrm{scc}, 3 \beta$-hydroxysteroid dehydrogenase (HSD), and 17 $\beta$-HSD activities, are diminished in PCB-exposed adult rat Leydig cells in vivo (Murugesan et al. 2005b). During normal metabolism, cells produce reactive oxygen species (ROS) that can damage DNA, protein, and lipids. In steroidogenic cells, ROS are produced by the electron transport chain. In addition, ROS are also produced during steroid hydroxylations by the cytochrome $\mathrm{P}_{450} \mathrm{scc}$ enzymes (Homsby 1989). In Leydig cells, ROS have been shown to have detrimental effects on critical components of the steroidogenic pathway (Quinn \& Payne 1985, Georgiou et al. 1987, Diemer et al. 2003, Murugesan et al. 2005b,c). In addition, the depletion of Leydig cellular antioxidant enzymes, and increase in the levels of ROS and lipid peroxidation were observed in PCB-exposed adult rats (Murugesan et al. 2005b). The role of ROS in PCB-induced testicular Leydig cell toxicity and their possible protection by vitamins $\mathrm{C}$ and $\mathrm{E}$ have been demonstrated recently (Murugesan et al. 2005c). Vitamin C scavenges aqueous phase ROS by very rapid electron transfer and thus inhibits lipid peroxidation and eliminates cytotoxic free radicals (Halliwell et al. 1987). Vitamin $\mathrm{E}$ is a major nonenzymatic antioxidant present in the lipid structure of cells (Burton et al. 1983), exerting its antioxidant effects by scavenging free radicals directly, thereby stabilizing membranes containing polyunsaturated fatty acids, and/or by downregulating mitochondrial superoxide generation (Burton et al. 1983, Chow 2004). Yet, the understanding of reproductive toxicities of PCBs on testicular Leydig cell function has mostly relied on the in vivo approach. However, the direct effects of PCB on StAR protein, activity and mRNA expression of steroidogenic enzymes, and antioxidant system are still unknown. Therefore, in the present study, we aimed to elucidate the direct effect of PCB on steroidogenesis, antioxidant system, and testosterone secretion in cultured rat Leydig cells.

\section{Materials and Methods}

\section{Chemicals}

Aroclor 1254, Dulbecco's modified Eagle's medium + Hams F-12 nutrient mixture (1:1; DMEM-F12), BSA, collagenase type IV, Percoll, Trypan blue, dehydroisoandrosterone, sodium pyrophosphate, androstenedione, testosterone, estradiol, fetal bovine serum (FBS), and dimethylsulfoxide (DMSO) were purchased from Sigma Chemical Company. $\left[{ }^{125} \mathrm{I}\right], \quad\left[26,27-{ }^{3} \mathrm{H}\right]-25$-hydroxycholesterol, ${ }^{3} \mathrm{H}$-testosterone, ${ }^{3} \mathrm{H}$-estradiol, and PD10 Sephadex G25 column were obtained from Amersham Pharmacia Biotech Asia Pacific Ltd. Testosterone antisera were a gift from Dr Nieschlag, Germany. All the other chemicals used were purchased from Sisco Research Laboratories, Mumbai, India and were of analytical grade. Total RNA isolation kit and primers for PCR were obtained from Biogene, Irvine, CA, USA and Integrated DNA Technologies, Coralville, IA, USA respectively. The RT-PCR kit was purchased from Qiagen.

\section{Animals}

Animals were maintained as per the national guidelines and protocols, approved by the institutional ethical committee (IAEC No. 03/005/02). Healthy adult male albino rats of Wistar strain Rattus norvegicus weighing 180-200 g (90 days old) were used in the present study.

\section{Isolation, purification, and identification of Leydig cells}

Twenty testes were decapsulated under aseptic conditions and Leydig cells were isolated by enzymatic digestion and purified on discontinuous Percoll gradient by the method described by Rigaudiere et al. (1988). In brief, testes were decapsulated with 
fine forceps without breaking the seminiferous tubules and digested in collagenase containing DMEM-F12 $(0 \cdot 25 \mathrm{mg} / \mathrm{ml})$ at $34{ }^{\circ} \mathrm{C}$ for $15 \mathrm{~min}$ in a thermostated shaking water bath. After this incubation, the tubes were added with DMEM-F12 without collagenase and allowed to stand for $10 \mathrm{~min}$. The supernatant was then aspirated using a Pasteur pipette and transferred to sterile centrifuge tubes. This procedure was repeated once again to remove additional Leydig cells. The supernatants were combined and centrifuged at $2500 \mathrm{~g}$ for 10 min at $4{ }^{\circ} \mathrm{C}$. After discarding the supernatant, the pellet obtained was resuspended in $1 \mathrm{ml}$ DMEM-F12 representing a crude testicular interstitial cell suspension.

Discontinuous Percoll gradients were used to obtain purified Leydig cells from this crude preparation. Two milliliters of $75 \%$ Percoll gradient was added to a graduated centrifuge tube. Above this layer, 60, 45, 30, 15, and 5\% gradients of Percoll ( $2 \mathrm{ml}$ each) were laid gently one over the other taking care to avoid mixing. One milliliter of crude Leydig cell suspension was then applied on top of this discontinuous gradient and centrifuged at $3000 \times \boldsymbol{g}$ for $30 \mathrm{~min}$ at $4{ }^{\circ} \mathrm{C}$. After centrifugation, most of the purified Leydig cells were observed in between 30 and $45 \%$ gradients. These Leydig cells were aspirated carefully using a Pasteur pipette and transferred to centrifuge tubes containing DMEM-F12. After mixing, the tubes were centrifuged at $2500 \times g$ for $10 \mathrm{~min}$ at $4{ }^{\circ} \mathrm{C}$ and the supernatant obtained was discarded. To remove excess Percoll, the cell pellets were washed thrice with excess medium and then finally suspended in $1 \mathrm{ml}$ DMEM-F12. The purity of Leydig cells was assessed by histochemical localization of $3 \beta-H S D$ performed according to the method of Aldred \& Cooke (1983), and the viability of the purified Leydig cells was determined by Trypan blue dye exclusion (Aldred \& Cooke 1983). The purity of Leydig cell was more than $95 \%$ and the viability was 93-95\%. The yield of Leydig cells per isolation was more than $20 \times 10^{6}$ cells.

\section{Primary culture of Leydig cells and Aroclor 1254 treatment}

Leydig cells were plated in $60 \mathrm{~mm}$ culture dish at a density of $1 \times 10^{6}$ cells with DMEM containing 3\% FBS. The cells were incubated for $24 \mathrm{~h}$ under $5 \% \mathrm{CO}_{2}$ and $95 \%$ air at $34{ }^{\circ} \mathrm{C}$. At the end of incubation, the FBS medium was removed and the cells were incubated with serum-free medium (SFM) for $1 \mathrm{~h}$ before the onset of experimental treatments. The cells were treated with SFM containing $10^{-10}, 10^{-9}, 10^{-8}$, and $10^{-7} \mathrm{M}$ Aroclor 1254 (mixed in $0.08 \%$ DMSO) for $24 \mathrm{~h}$ without or with $\mathrm{LH}$ stimulation $(100 \mathrm{ng} / \mathrm{ml})$. The control Leydig cells were treated with DMSO, the vehicle used. After the experimental period, conditioned media were collected and used for the assay of testosterone and estradiol. The cell viabilities of the control and the treated cells were determined by Trypan blue dye exclusion method (Aldred \& Cooke 1983). The treated Leydig cells were used for the measurement of $\mathrm{LH}$ receptor number, steroidogenic enzymes, antioxidant system, mRNAs for steroidogenic acute-regulatory protein, cytochrome $\mathrm{P}_{450} \mathrm{scc}, 3 \beta-\mathrm{HSD}$, $17 \beta-\mathrm{HSD}$, and ribosomal protein S16 (RPS 16) was used as an internal control.

\section{RIA of testosterone and estradiol}

The conditioned media were assayed for testosterone and estradiol using liquid-phase RIA as described by Sufi et al. (1986). The inter- and intraassay coefficients of variation were $4-4 \cdot 5$ and $3 \cdot 2-5 \%, 4 \cdot 5-10$ and $3 \cdot 2-4 \cdot 9 \%$ for testosterone and estradiol respectively. The sensitivity of the testosterone assay was $0.06 \mathrm{ng} / \mathrm{ml}$ and the cross-reactivity of the testosterone antiserum was $24 \%$ for dihydrotestosterone, $1.8 \%$ for androstenedione, and $0.001 \%$ for cortisol. The sensitivity of estradiol assay was $6 \mathrm{pg} / \mathrm{ml}$ and the cross-reactivity of the estradiol antiserum was $16 \%$ for estriol, $1 \cdot 0 \%$ for estrone and progesterone, and $0 \cdot 001 \%$ for testosterone.

\section{Assay of Leydig cell-surface $L H$ receptors using ${ }^{125} I-h C G$}

Labeling of hormone Purified human chorionic gonadotropin (hCG) was labeled with $\left[{ }^{125} \mathrm{I}\right]$ following the lactoperoxidase method described by Thorell \& Johannson (1971).

${ }^{125}$ I-hCG-binding assay After 24-h Aroclor 1254 treatment with or without LH stimulation, the medium was removed and the cells incubated for $16 \mathrm{~h}$ at $4{ }^{\circ} \mathrm{C}$ with medium containing saturating concentration of ${ }^{125} \mathrm{I}-\mathrm{hCG}$ in the presence or absence of increasing concentration of unlabeled hCG. Nonspecific binding (NSB) was determined with excess unlabeled hCG $(1 \mu \mathrm{g})$. At the end of the incubation period, the medium was removed and the cells washed twice with PBS. The cultured cells were then solubilized with $0 \cdot 1 \mathrm{M} \mathrm{NaOH}$ and the cell surface-bound radioactivity determined by counting in a gamma counter. The specific binding of ${ }^{125} \mathrm{I}-\mathrm{hCG}$ was calculated by subtracting NSB from the total cell surface-bound radioactivity. The data were subjected to Scatchard analysis to determine the concentration of receptors.

\section{Assay of steroidogenic enzymes}

Cytochrome $\mathbf{P}_{\mathbf{4 5 0}}$ scc enzyme activity $\mathrm{P}_{450} \mathrm{scc}$ enzyme activity was determined radiometrically as per the method of Georgiou et al. (1987) by measuring the conversion of $\left[26,27-{ }^{3} \mathrm{H}\right]-25$-hydroxycholesterol to ${ }^{3} \mathrm{H}$-labeled, 4-hydroxyl-4-methyl-pentanoic acid. Cultured Leydig cells were washed twice with fresh medium to remove endogenous substrates. Then the enzyme activity was determined by incubating the culture tubes with saturating concentration of $\left[26,27-{ }^{3} \mathrm{H}\right]-25$-hydroxycholesterol $(5 \mu \mathrm{m} ; 0 \cdot 5 \mu \mathrm{Ci})$ in $100 \mathrm{mM}$ DMSO at $34{ }^{\circ} \mathrm{C}$ for $1 \mathrm{~h}$ in a $\mathrm{CO}_{2}$ incubator. The enzyme reaction was stopped by the addition of $0 \cdot 1 \mathrm{ml}$ of $1 \mathrm{M}$ $\mathrm{NaOH}$, and 3000 c.p.m. $\left[{ }^{14} \mathrm{C}\right]$ isocaproic acid was added as a 
recovery standard. The medium was removed to an extraction tube, and the culture tube was washed with $1 \mathrm{ml}$ alkalinized medium, which was combined with $1 \mathrm{ml}$ original medium and extracted with $10 \mathrm{ml}$ chloroform. One and a half milliliter of extracted aqueous phase were vortexed with $0 \cdot 8 \mathrm{~g}$ neutral alumina for $1 \mathrm{~min}$, followed by centrifugation at $1200 \times \boldsymbol{g}$ for $25 \mathrm{~min}$. The supernatant aqueous phase $(0 \cdot 4 \mathrm{ml})$ was transferred to scintillation vials containing cocktail toluene and the radioactivity was measured using liquid scintillation counter.

3 $\beta$-HSD enzyme activity The activity of $3 \beta-H S D$ in cultured Leydig cells was determined by the method described by Bergmeyer (1974). In brief, the cultured Leydig cells were sonicated in ice-cold Tris- $\mathrm{HCl}$ buffer $(\mathrm{pH} 7 \cdot 2)$ and centrifuged at $16000 \times \boldsymbol{g}$ for $5 \mathrm{~min}$ at $4{ }^{\circ} \mathrm{C}$. The supernatant was used as enzyme extract for the assay of $3 \beta$-HSD. The reaction mixture contained $0.6 \mathrm{ml}$ pyrophosphate buffer $(100 \mu \mathrm{M}), 0 \cdot 2 \mathrm{ml}$ NAD $(0 \cdot 5 \mu \mathrm{M}), 2 \mathrm{ml}$ distilled water, and $0 \cdot 1 \mathrm{ml}$ dehydroisoandrosterone $(0 \cdot 1 \mu \mathrm{M})$. The absorbance at $340 \mathrm{~nm}$ was measured immediately after the addition of enzyme extract at 20-s intervals for $5 \mathrm{~min}$ in a spectrophotometer against blank.

$17 \boldsymbol{\beta}-\mathrm{HSD}$ enzyme activity The activity of $17 \boldsymbol{\beta}-\mathrm{HSD}$ in Leydig cells was determined by the method described by Bergmeyer (1974). In brief, the cultured Leydig cells were sonicated in ice-cold Tris-HCl buffer $(\mathrm{pH} 7 \cdot 2)$ and centrifuged at $10000 \times \boldsymbol{g}$ for $5 \mathrm{~min}$ at $4{ }^{\circ} \mathrm{C}$. The supernatant was used as enzyme extract for the assay of $17 \beta-H S D$. The reaction mixture contained $0.6 \mathrm{ml}$ pyrophosphate buffer $(100 \mu \mathrm{M}), 0 \cdot 2 \mathrm{ml} \mathrm{NADPH}(0.5 \mu \mathrm{M}), 2 \mathrm{ml}$ distilled water, and $0.1 \mathrm{ml}$ of 1,4 -androstenedine-3,17-dione $(0 \cdot 8 \mu \mathrm{M})$. The absorbance at $340 \mathrm{~nm}$ was measured immediately after the addition of enzyme extract at 30-s intervals for $5 \mathrm{~min}$ in a spectrophotometer against blank.

\section{Leydig cellular antioxidant system}

After 24-h Aroclor 1254 treatment with or without LH stimulation, the cultured Leydig cells were sonicated in

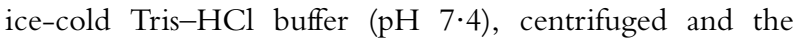
supernatant was collected and used for measuring the following biochemical parameters.

Determination of lipid peroxidation Protein content was determined by the method of Lowry et al. (1951). The level of lipid peroxidation was measured by the method of Devasagayam \& Tarachand (1987). In brief, the reaction mixture consisted of $1.0 \mathrm{ml}$ of $0 \cdot 15 \mathrm{M}$ Tris- $\mathrm{HCl}$ buffer $(\mathrm{pH}$ $7 \cdot 4), 0.3 \mathrm{ml}$ of $10 \mathrm{mM} \mathrm{KH}_{2} \mathrm{PO}_{4}$, and $0.2 \mathrm{ml}$ cell extract in a total volume of $2 \mathrm{ml}$. The tubes were incubated at $37{ }^{\circ} \mathrm{C}$ for $20 \mathrm{~min}$ with constant shaking. The reaction was stopped by the addition of $1 \mathrm{ml} \mathrm{10 \%} \mathrm{trichloroacetic} \mathrm{acid.} \mathrm{The} \mathrm{tubes} \mathrm{were}$ shaken well, $1.5 \mathrm{ml}$ thiobarbituric acid (TBA) added and were heated in a boiling water bath for $20 \mathrm{~min}$. Standard tubes containing $10,20,30,40$, and $50 \mathrm{nmol} / \mathrm{ml}$ were also run simultaneously. The tubes were centrifuged and the color developed was measured at $532 \mathrm{~nm}$. The malondialdehyde (MDA) content of the sample is expressed as nanomoles of MDA formed per milligram protein.

Determination of reactive oxygen species Hydrogen peroxide was quantified by the method of Holland \& Storey (1981). In brief, to the assay mixture containing $0 \cdot 1 \mathrm{ml} \mathrm{KCl}$ $(1.13 \mathrm{M}), 0.1 \mathrm{ml}$ potassium phosphate $(150 \mathrm{mM}), 0.05 \mathrm{ml}$ $\mathrm{MgCl}_{2}(60 \mathrm{mM}), 0 \cdot 05 \mathrm{ml}$ EDTA $(8 \mathrm{mM}), 0 \cdot 1 \mathrm{ml}$ Tris- $\mathrm{HCl}$ (200 mM, pH 7.4), $0 \cdot 1 \mathrm{ml}$ of $1 \mathrm{mM}$ acetylated ferrocytochrome $\mathrm{c}$, and $0.1 \mathrm{ml}$ cell extract were added and the oxidation of ferrocytochrome $\mathrm{c}$, which gives the measure of $\mathrm{H}_{2} \mathrm{O}_{2}$ production was measured at $550 \mathrm{~nm}$, in a spectrophotometer. The $\mathrm{H}_{2} \mathrm{O}_{2}$ content of the sample is expressed as $\mu \mathrm{mol} / \mathrm{min}$ per mg protein.

Hydroxyl radical production was quantified by the method of Puntarulo \& Cederbaum (1988). In brief, to a $1 \mathrm{ml}$ cell extract, $0.2 \mathrm{ml}$ of $1 \mathrm{M}$ phosphate buffer, $0.1 \mathrm{ml}$ of each of magnesium chloride, sodium azide, DMSO, and NADPH were added and incubated for $10 \mathrm{~min}$ at $37{ }^{\circ} \mathrm{C}$. The reaction was arrested by adding $0.5 \mathrm{ml}$ chromotropic acid, boiled for $30 \mathrm{~min}$, and read at $570 \mathrm{~nm}$, against the reagent blank. The hydroxyl radical content of the samples is expressed as $\mu \mathrm{mol} /$ min per mg protein.

\section{Antioxidant enzymes assay}

Determination of superoxide dismutase (enzyme commission (EC) 1.15.1.1, SOD) The activity of SOD was assayed according to the method of Marklund \& Marklund (1974). Briefly, to the assay mixture containing $0.5 \mathrm{ml}$ cell extract, $0.25 \mathrm{ml}$ absolute ethanol and $0.15 \mathrm{ml}$ chloroform were added. After 15-min shaking in a mechanical shaker, the suspension was centrifuged and the supernatant was used for the assay. The reaction mixture for auto-oxidation consisted of $2 \mathrm{ml}$ Tris- $\mathrm{HCl}$ buffer $(\mathrm{pH} 8 \cdot 2)$, $0.5 \mathrm{ml}$ of $2 \mathrm{mM}$ pyrogallol, and $1.5 \mathrm{ml}$ distilled water. Initially, the rate of auto-oxidation of pyrogallol was noted at intervals of $1 \mathrm{~min}$, for $3 \mathrm{~min}$. This was considered as $100 \%$ auto-oxidation. The assay mixture for the enzyme contained $2 \mathrm{ml}$ Tris- $\mathrm{HCl}$ buffer ( $\mathrm{pH} \mathrm{8.2)}, 2 \mathrm{ml}$ distilled water, $0.5 \mathrm{ml}$ enzyme preparation, and $0.5 \mathrm{ml}$ of $2 \mathrm{mM}$ pyrogallol. The samples were immediately read at $470 \mathrm{~nm}$ against blank containing all components except the enzyme and pyrogallol at intervals of $1 \mathrm{~min}$, for $3 \mathrm{~min}$ on a spectrophotometer. The enzyme activity is expressed as units per milligram protein.

Determination of catalase (EC 1.11.1.6, CAT) The activity of CAT was assayed by the method of Sinha (1972). Briefly, the assay mixture contained $0.5 \mathrm{ml}$ of $0.2 \mathrm{M} \mathrm{H}_{2} \mathrm{O}_{2}$, $1 \mathrm{ml}$ sodium phosphate buffer, and $0.4 \mathrm{ml}$ distilled water. Subsequently, $0 \cdot 1 \mathrm{ml}$ cell extract was added to initiate the reaction. Then, $2 \mathrm{ml}$ dichromate-acetic acid reagent was added after $15,30,45$, and $60 \mathrm{~s}$, to arrest the reaction. To the 
control tube, the enzyme was added after the addition of the dichromate-acetic acid reagent. The tubes were then heated for $10 \mathrm{~min}$, allowed to cool, and the green color that developed was read at $590 \mathrm{~nm}$ against blank containing all components except the enzyme in a spectrophotometer. The activity of CAT is expressed as units per milligram protein ( $1 \mathrm{U}$ is the amount of enzyme that utilizes $1 \mu \mathrm{mol}$ hydrogen peroxide/min).

Determination of glutathione peroxidase (EC 1.11.1.9, GPx) The activity of GPx was determined by the method of Rotruck et al. (1973). Briefly, the assay mixture containing $0.5 \mathrm{ml}$ sodium phosphate buffer, $0.1 \mathrm{ml}$ of $10 \mathrm{mM}$ sodium azide, $0.2 \mathrm{ml}$ of $4 \mathrm{mM}$ reduced glutathione, $0.1 \mathrm{ml}$ of $2.5 \mathrm{mM} \mathrm{H}_{2} \mathrm{O}_{2}$, and $0.5 \mathrm{ml}$ of 1:10 cell extract was taken and the total volume was made up to $2 \cdot 0 \mathrm{ml}$ with distilled water. The tubes were incubated at $37{ }^{\circ} \mathrm{C}$ for $3 \mathrm{~min}$ and the reaction was terminated by the addition of $0.5 \mathrm{ml}$ of $10 \%$ trichloroacetic acid (TCA). To determine the residual glutathione content, the supernatant was removed after centrifugation, and to this $4.0 \mathrm{ml}$ disodium hydrogen phosphate $(0.3 \mathrm{M})$ solution and $1 \mathrm{ml}$ dithio-bis-nitrobenzoic acid (DTNB) reagent were added. The color that developed was read at $412 \mathrm{~nm}$ against a reagent blank containing only phosphate solution and DTNB reagent in a spectrophotometer. Suitable aliquots of the standard were also treated similarly. The enzyme activity is expressed as units per milligram protein $(1 \mathrm{U}$ is the amount of enzyme that converts $1 \mu \mathrm{mol}$ reduced glutathione (GSH) to GSSG in the presence of hydrogen peroxide/min).

Determination of glutathione reductase (EC 1.6.4.2, GR) The activity of GR was determined by the method of Staal et al. (1969). Briefly, to the assay mixture containing $0.2 \mathrm{ml}$ cell extract, $1.5 \mathrm{ml}$ sodium phosphate buffer, $0.5 \mathrm{ml}$ of $25 \mathrm{mM}$ EDTA, $0 \cdot 2 \mathrm{ml}$ of $12.5 \mathrm{mM}$ oxidized glutathione, and $0 \cdot 1 \mathrm{ml}$ of $3 \mathrm{mM}$ NADPH were added and immediately read at $340 \mathrm{~nm}$ against blank containing all the components except the enzyme for $3 \mathrm{~min}$ at 30 -s interval in a spectrophotometer. The activity of GR is expressed as micromoles of NADPH oxidized/min per mg protein.

Determination of $\gamma$-glutamyl transpeptidase (EC 2.3.2.2, $\gamma$-GT) The enzyme activity was estimated by the method of Orlowski \& Meister (1965). Briefly, the assay mixture contained $0.5 \mathrm{ml}$ substrate (L- $\gamma$-glutamyl- $p$-nitroaniline), $1 \mathrm{ml}$ Tris- $\mathrm{HCl}$ buffer, $2 \cdot 2 \mathrm{ml}$ glycyl-glycine, and $0 \cdot 2 \mathrm{ml}$ cell extract. The total volume was made up to $4 \mathrm{ml}$ with distilled water. After incubation for $30 \mathrm{~min}$ at $37^{\circ} \mathrm{C}$, the reaction was arrested by the addition of $1 \mathrm{ml}$ of $10 \%$ acetic acid to the test and control tubes. The control tubes received substrate after incubation. Standard $p$-nitroaniline was also treated similarly. The amount of liberated $p$-nitroaniline in the supernatant was with and without the substrate. The substrate incubated in the absence of enzyme under the same condition was used as a reference blank. The optical density (OD) was measured against blank at $410 \mathrm{~nm}$ in a spectrophotometer.
The enzyme activity is expressed as micromoles of $p$-nitroaniline formed/min per $\mathrm{mg}$ protein of cell extract.

Determination of glutathione- $S$-transferase (EC 2.5.1.1.8, GST) This enzyme was assayed by the method of Habig et al. (1974). Briefly, to the assay mixture containing $0.4 \mathrm{ml}$ potassium phosphate buffer, $0.1 \mathrm{ml}$ cell extract, $1.2 \mathrm{ml}$ distilled water, and $0.1 \mathrm{ml}$ 1-chloro-2,4-dinitrobenzene (CDNB) were added and incubated in a water bath at $37{ }^{\circ} \mathrm{C}$ for $10 \mathrm{~min}$. After incubation, $0 \cdot 1 \mathrm{ml}$ of $30 \mathrm{mM}$ reduced glutathione was added. The optical density was measured immediately against a reagent blank at $340 \mathrm{~nm}$ at intervals of $30 \mathrm{~s}$, for $3 \mathrm{~min}$ in a spectrophotometer. The activity of GST is expressed as units/mg protein $(1 \mathrm{U}$ is the amount of enzyme that conjugates $1 \mathrm{nmol} \mathrm{CDNB}$ with $\mathrm{GSH} / \mathrm{min})$.

Determination of nonenzymatic antioxidants The nonenzymatic antioxidants, such as vitamins $\mathrm{C}$ and $\mathrm{E}$, were estimated as per the method of Omaye et al. (1979) and Desai (1984) respectively.

\section{$R T-P C R$}

Total RNA was isolated from control and treated Leydig cells $\left(5-8 \times 10^{6}\right)$ with $10^{-8}$ and $10^{-7} \mathrm{M}$ concentration for $24 \mathrm{~h}$ using EZ-10 spin column total RNA minipreps super kit (Biogene) according to the manufacture's instructions. The RNA purity and concentration were determined spectrophotometrically at $A_{260} / A_{280} \mathrm{~nm}$. The purity of RNA we obtained was $1 \cdot 8-1 \cdot 9$.

Two micrograms of total RNA were reverse transcribed by Qiagen one-step RT-PCR kit according to the manufacture's instructions and further amplified by PCR. The details of the primers used, number of cycles, and size of the PCRamplified products are listed in Table 1 . The primers used for RT-PCR for StAR protein and cytochrome $\mathrm{P}_{450} \mathrm{scc}$ were gene-specific primers selected according to Akingbemi et al. (2004). The $3 \beta-H S D$ type I and $17 \beta-H S D$ type III were selected according to Sakaue et al. (2002).Ten microliters of each PCR product were analyzed by gel electrophoresis on a $2 \%$ agarose gel. The molecular size of the amplified products (StAR, P450scc, 3 $\beta-H S D, 17 \beta-H S D$, and RPS 16) was determined by comparison with molecular weight marker (100 bp DNA ladder) run in parallel with RT-PCR products. The gels were then subjected to densitometric scanning (Bio-Rad) to find out the OD units of each band and then normalized against that of the internal control (RPS 16).

\section{Statistical analysis}

Data are expressed as the mean \pm S.E.M. The group mean differences were determined by one-way ANOVA. If group differences were revealed by ANOVA $(P<0 \cdot 05)$, differences between individual groups were determined using Student's $t$-test. Values were considered significant at $P<0 \cdot 05$. 
Table 1 Details of primers employed, number of cycles, and expected size of the PCR-amplified cDNA

\begin{tabular}{|c|c|c|c|}
\hline & Sequence of the primer & No. of cycles & Product size $(b p)$ \\
\hline \multirow[t]{4}{*}{ StAR } & Forward primer & & \\
\hline & $5^{\prime}$-TTG GGC ATA CTC AAC AAC CA-3' & & \\
\hline & Reverse primer & 35 & 389 \\
\hline & 5'-ATG ACA CCG CTT TGC TCA G-3' & & \\
\hline \multirow[t]{4}{*}{$\mathrm{P}_{450} \mathrm{SCC}$} & Forward primer & & \\
\hline & 5'-AGG TGT AGC TCA GGA CTT-3' & & \\
\hline & Reverse primer & 35 & 399 \\
\hline & $5^{\prime}$-AGG AGG CTA TAA AGG ACA CC-3' & & \\
\hline \multirow[t]{4}{*}{ 3ß-HSD (type I) } & Forward primer & & \\
\hline & $5^{\prime}$-TTG GTG CAG GAG GAA AGA AC-3' & & \\
\hline & Reverse primer & 35 & 547 \\
\hline & 5'-CCG CAA GTA TCA TGA CAG A-3' & & \\
\hline \multirow[t]{4}{*}{ 17ß-HSD (type III) } & Forward primer & & \\
\hline & 5'-TTC TGC AAG GCT TTA CCA GG-3' & & \\
\hline & Reverse primer & 35 & 653 \\
\hline & 5'-ACA ȦAC TCA TCG GCG GCT T T-3' & & \\
\hline \multirow[t]{4}{*}{ RPS 16} & Forward primer & & \\
\hline & 5'-AAG TCT TCG GAC GCA AGA AA-3' & & \\
\hline & Reverse primer & 35 & 148 \\
\hline & $5^{\prime}$-TTG CCC AGA AGC AGA ACA G-3' & & \\
\hline
\end{tabular}

\section{Results}

\section{Effect of Aroclor 1254 on cell viability}

Figure 1 shows cell viability in control and Aroclor 1254exposed Leydig cells under basal and LH-stimulated conditions for $24 \mathrm{~h}$. The viable cells were significantly reduced only due to $10^{-7} \mathrm{M}$ treatment in both basal and LH-stimulated conditions when compared with respective control. However, other treatments did not alter the cell viability.

\section{Testosterone and estradiol secretion}

Figure 2 shows testosterone and estradiol secretion in control and Aroclor 1254-exposed Leydig cells under basal and

\section{Cell viability}

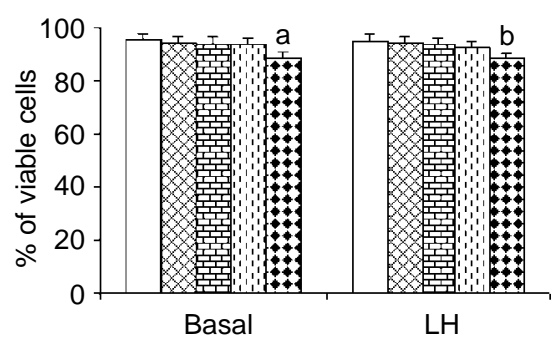

Control $10^{-10} \mathrm{M}$ 吕 $10^{-9} \mathrm{M}$. $10^{-7} \mathrm{M}$

Figure 1 Dose-dependent effects of PCB (Aroclor 1254) on basal and $\mathrm{LH}$-stimulated Leydig cell viabilities in vitro. Each bar denotes mean \pm S.E.M of three independent experiments carried out in duplicates. Significance at $P<0.05 ;$ a, compared with basal; b, compared with LH-stimulated.
LH-stimulated conditions. Testosterone level in the medium was significantly decreased in Aroclor 1254-exposed Leydig cells at $10^{-9}, 10^{-8}$, and $10^{-7} \mathrm{M}$ treatment under basal and LH-stimulated conditions when compared with respective control. However, estradiol was diminished by $10^{-8}$ and $10^{-7} \mathrm{M}$ Aroclor 1254 treatment, whereas in the LH-stimulated condition, the estradiol production was reduced by $10^{-9}, 10^{-8}$, and $10^{-7} \mathrm{M}$ Aroclor 1254 treatment.

\section{Leydig cell $\mathrm{LH}$ receptors}

Figure 3 compares hCG-binding sites in control and Aroclor 1254-exposed Leydig cells under basal and LH-stimulated conditions. The number of binding sites was significantly diminished in Aroclor 1254-exposed Leydig cells in a dosedependent manner under basal and LH-stimulated conditions when compared with respective control.
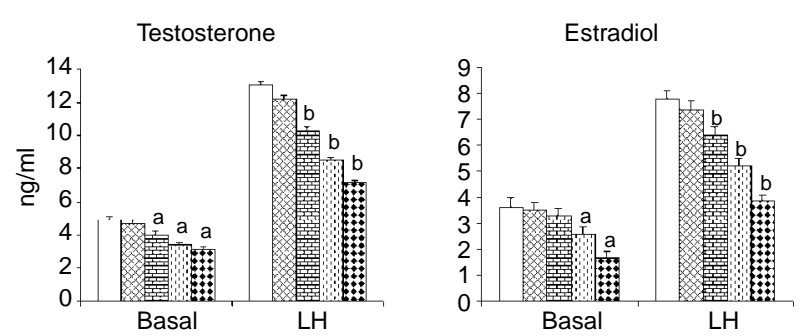

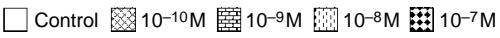

Figure 2 Dose-dependent effects of PCB (Aroclor 1254) on basal and LH-stimulated testosterone and estradiol production by Leydig cells in vitro. Each bar denotes mean \pm S.E.M of three independent experiments carried out in duplicates. Significance at $P<0.05$; a, compared with basal; b, compared with LH-stimulated. 
hCG binding sites

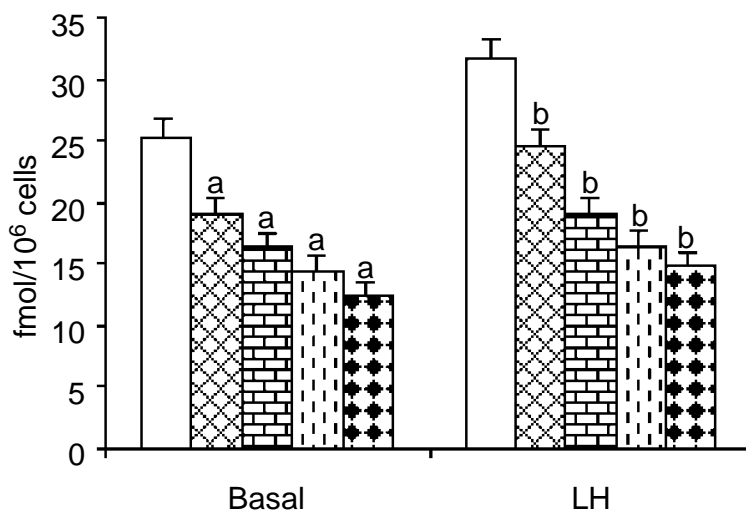

Cytochrome $\mathrm{P}_{450}$ scc activity
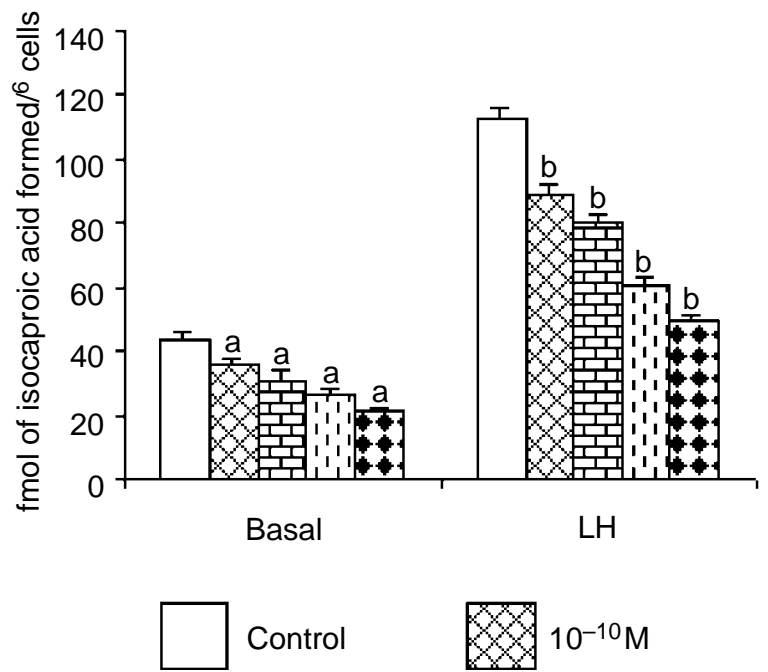

3ß-HSD activity
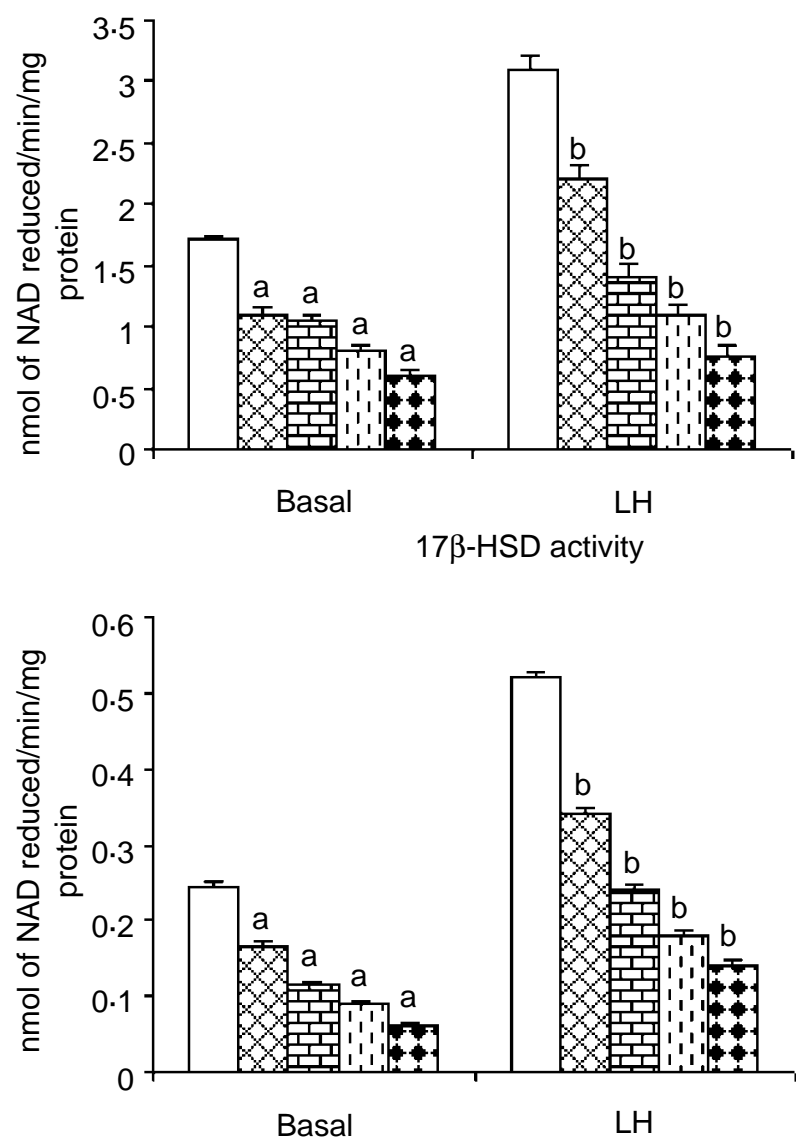

Figure 3 Dose-dependent effects of PCB (Aroclor 1254) on basal and LH-stimulated [ ${ }^{125}$ I]hCG-binding sites and steroidogenic enzymes activities of Leydig cells in vitro. Each bar denotes mean \pm s.E.M of three independent experiments carried out in duplicates. Significance at $P<0 \cdot 05 ; \mathrm{a}$, compared with basal; b, compared with LH-stimulated.

\section{Leydig cellular steroidogenic enzymes}

Figure 3 shows the effect of Aroclor 1254 on Leydig cellular steroidogenic enzyme activities, such as cytochrome $\mathrm{P}_{450} \mathrm{scc}$, $3 \beta-H S D$, and $17 \beta-H S D$, under basal and LH-stimulated conditions. The activities of $\mathrm{P}_{450} \mathrm{scc}, 3 \beta-\mathrm{HSD}$ and $17 \beta-\mathrm{HSD}$ in Aroclor 1254-exposed Leydig cells were significantly diminished in a dose-dependent manner under basal and LH-stimulated conditions when compared with respective control.

\section{Lipid peroxidation and reactive oxygen species}

Figure 4 compares the levels of lipid peroxidation and reactive oxygen species, such as hydrogen peroxide and hydroxyl radical production, in control and Aroclor 1254-exposed Leydig cells under basal and LH-stimulated conditions.
The lipid peroxidation, hydrogen peroxide, and hydroxyl radical production were significantly elevated in Aroclor 1254-exposed Leydig cells in a dose-dependent manner under basal and LH-stimulated conditions when compared with respective control.

\section{Leydig cellular antioxidant enzymes}

Figures 5 and 6 provide data on cellular levels of antioxidant enzymes, such as SOD, CAT, GPx, GR, $\gamma$-GT, and GST in control and Aroclor 1254-exposed Leydig cells under basal and LH-stimulated conditions. The antioxidant enzymes, such as SOD, CAT, GPx, GR, $\gamma$-GT, and GST, were significantly diminished in a dose-dependent manner under basal and LH-stimulated conditions when compared with respective control. 
Lipid peroxidation
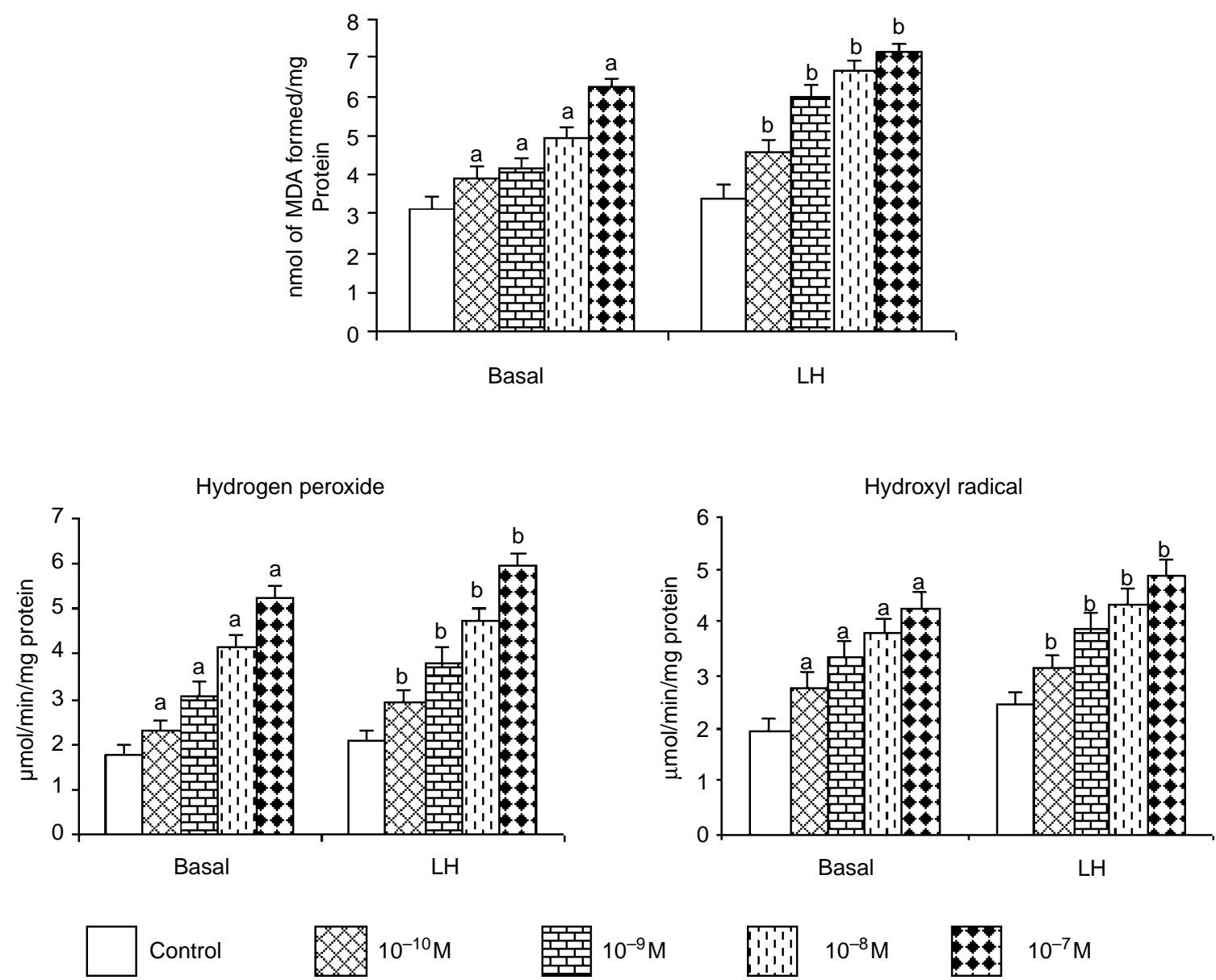

Figure 4 Dose-dependent effects of PCB (Aroclor 1254) on basal and LH-stimulated lipid peroxidation and reactive oxygen species of Leydig cells in vitro. Each bar denotes mean \pm s.E.M of three independent experiments carried out in duplicates. Significance at $P<0 \cdot 05$; a, compared with basal; b, compared with LH-stimulated.

\section{Leydig cellular nonenzymatic antioxidants}

Figure 7 shows data on cellular levels of nonenzymatic antioxidants, such as vitamins $\mathrm{C}$ and $\mathrm{E}$, in control and Aroclor 1254-exposed Leydig cells under basal and LH-stimulated conditions. The nonenzymatic antioxidants, such as vitamins $\mathrm{C}$ and $\mathrm{E}$, were significantly decreased in a dose-dependent manner under basal and LH-stimulated conditions when compared with respective control.

\section{Steroidogenic acute-regulatory (StAR) protein and steroidogenic} enzymes $m R N A$ expression

To elucidate the molecular mechanism underlying the PCB-induced reduction of testosterone production, we measured the mRNA expression levels of StAR protein and steroidogenic enzymes, such as cytochrome $\mathrm{P}_{450}$ scc, $3 \beta$-HSD, and $17 \beta-$ HSD, using RT-PCR (Figs $8-10$ ). The StAR protein mRNA level was significantly reduced by $10^{-7} \mathrm{M}$ treatment alone. However, steroidogenic enzymes, such as cytochrome $\mathrm{P}_{450} \mathrm{scc}, 3 \beta-\mathrm{HSD}$, and $17 \beta-\mathrm{HSD}$, were drastically decreased by both $10^{-8}$ and $10^{-7} \mathrm{M}$ treatment when compared with control.

\section{Discussion}

The present study demonstrates that PCB inhibits basal and LH-stimulated testosterone production in Leydig cells. Disruption of androgen biosynthesis in the Leydig cells has been associated with diminished $\mathrm{LH}$ receptors, activities of steroidogenic enzymes, such as cytochrome $\mathrm{P}_{450} \mathrm{scc}, 3 \beta-\mathrm{HSD}$, and $17 \beta$-HSD, enzymatic antioxidants such as SOD, CAT, GPx, GR, GST, and $\gamma$-GT, and nonenzymatic antioxidants, such as vitamins $\mathrm{C}$ and $\mathrm{E}$ by acting directly on Leydig cells. 
Superoxide dismutase

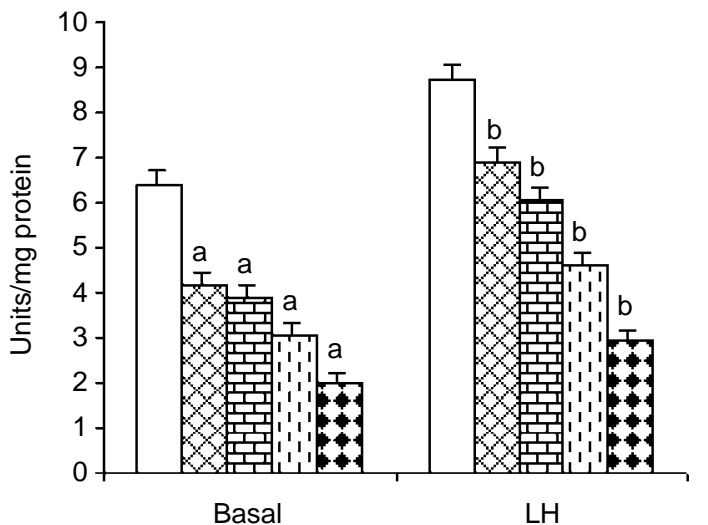

Glutathione peroxidase

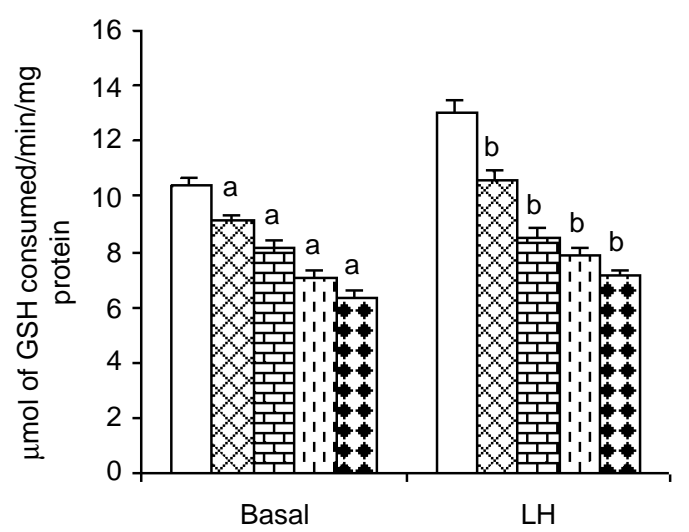

LH

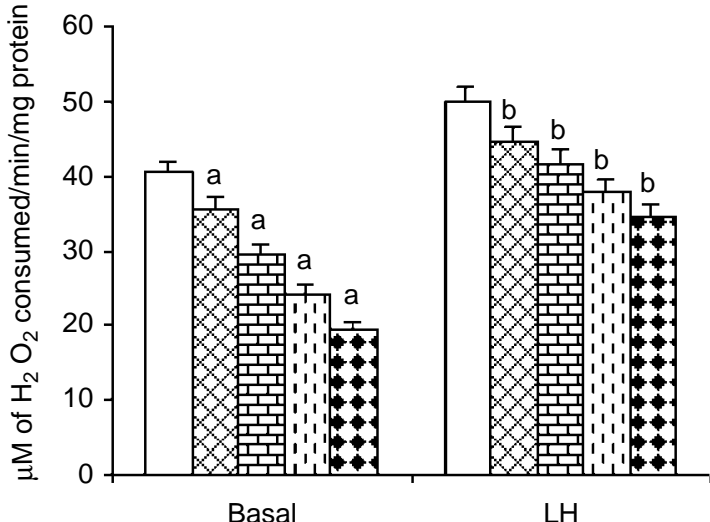

Glutathione reductase

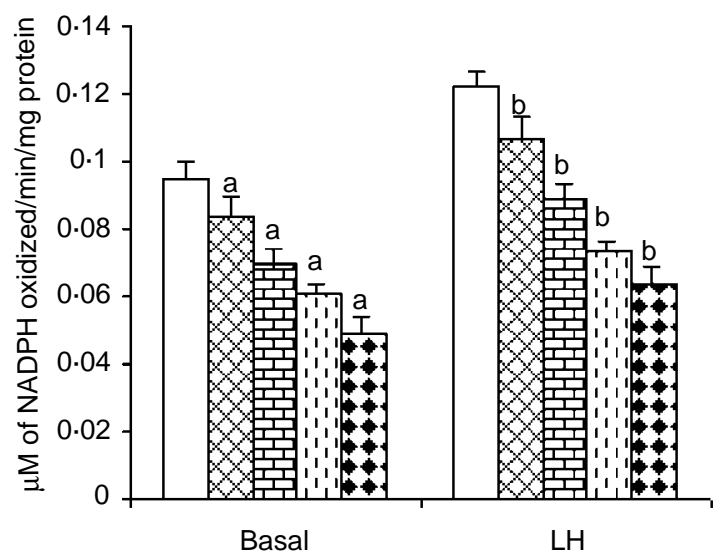

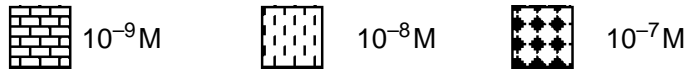

Figure 5 Dose-dependent effects of PCB (Aroclor 1254) on basal and LH-stimulated antioxidant enzymes, such as SOD, CAT, GPx, and GR activities of Leydig cells in vitro. Each bar denotes mean \pm s.E.M of three independent experiments carried out in duplicates. Significance at $P<0 \cdot 05$; a, compared with basal; b, compared with LH-stimulated.

However, the Leydig cellular lipid peroxidation (LPO) and ROS were significantly elevated in a dose-dependent manner in basal and LH-stimulated conditions. In addition to this, the StAR protein mRNA level was decreased by $10^{-7} \mathrm{M}$ treatment alone, whereas steroidogenic enzymes, such as cytochrome $\mathrm{P}_{450} \mathrm{scc}, 3 \beta-\mathrm{HSD}$, and $17 \beta-\mathrm{HSD}$ mRNAs levels, were drastically reduced by both $10^{-8}$ and $10^{-7} \mathrm{M}$ Aroclor 1254 treatment.

In the present study, the percentage of viable cells was significantly reduced only by $10^{-7} \mathrm{M}$ Aroclor 1254 treatments in both basal and LH-stimulated conditions as assessed by Trypan blue exclusion (Aldred \& Cooke 1983). Cytotoxic effects of PCB were dose-dependent with $10^{-8} \mathrm{M}$ or lower concentrations exhibiting no significant impairment of Leydig cell viability. The Trypan blue dye exclusion assay depends on intact cellular membranes as a measure of viability. These data suggest that exposure to PCB treatments $\left(10^{-7} \mathrm{M}\right)$ causes significant alterations in the plasma membrane. PCB acts directly on Leydig cells because it decreased testosterone production in vitro. The inhibition of steroidogenesis was associated with diminished $\mathrm{LH}$ receptor number and steroidogenic enzyme activities in basal and LH-stimulated conditions. Previous in vivo studies from our laboratory revealed a significant reduction in Leydig cell LH receptors due to PCB treatment for 30 days. We speculated that diminished cell-surface LH receptor may be due to elevated levels of ROS and LPO in rats subjected to PCB exposure. However, the simultaneous administration of 


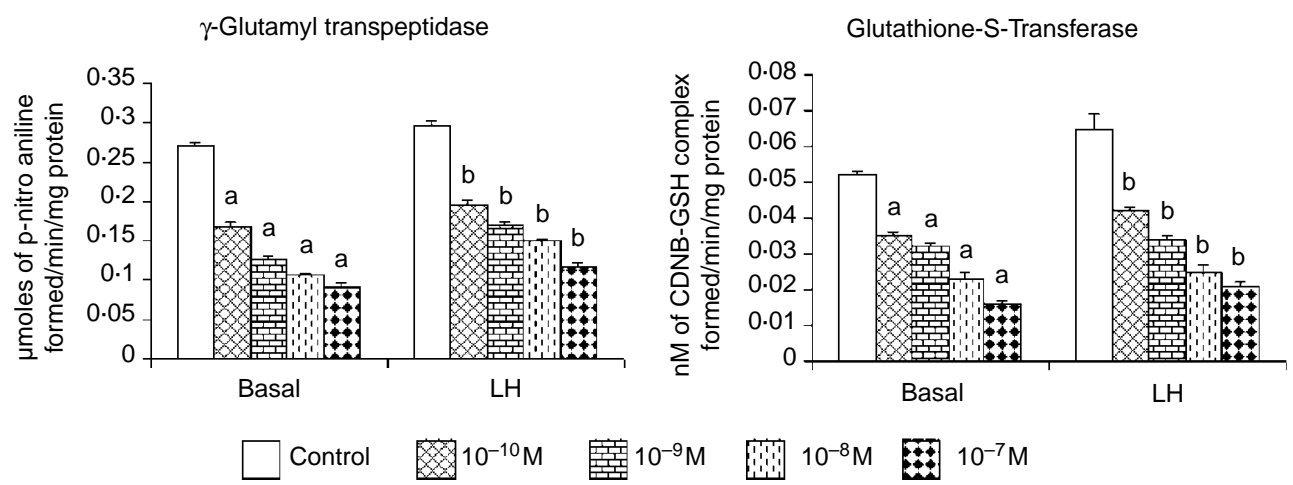

Figure 6 Dose-dependent effects of PCB (Aroclor 1254) on basal and LH-stimulated antioxidant enzymes, such as $\gamma$-GT and GST activities of Leydig cells in vitro. Each bar denotes mean \pm s.E.M of three independent experiments carried out in duplicates. Significance at $P<0.05$; a, compared with basal; $\mathrm{b}$, compared with LH-stimulated.

vitamins $\mathrm{C}$ and $\mathrm{E}$ maintained the $\mathrm{LH}$ receptor concentration (Murugesan et al. 2005b,c). The present in vitro study also supports the notion of increased levels of ROS and LPO being associated with decreased levels of cell-surface LH receptor concentration under basal and LH-stimulated conditions. Furthermore, exposure to 2,3,7,8-tetrachlorodibenzo-p-dioxin in mouse led to suppression of the $\mathrm{LH}$ receptor gene in the testis (Fukuzawa et al. 2004).

The synthesis of testosterone is dependent upon the expression of highly regulated genes, such as StAR, $\mathrm{P}_{450} \mathrm{scc}$, $3 \beta-H S D$, and $17 \beta-H S D$. StAR protein controls the ratelimiting step in steroidogenesis that is the transport of cholesterol from the outer to the inner mitochondrial membrane (Stocco 2001). In the present study, the StAR mRNA expression was decreased only in $10^{-7} \mathrm{M}$ Aroclor 1254-exposed Leydig cells. Several observations led us to hypothesize that environmental toxicants, such as lindane, roundup, and manganese block steroidogenesis via the disruption of StAR gene expression (Walsh \& Stocco 2000, Walsh et al. 2000, Cheng et al. 2003, 2005). The expression of steroidogenic enzymes, such as cytochrome $\mathrm{P}_{450} \mathrm{scc}, 3 \beta-\mathrm{HSD}$, $\mathrm{P}_{450} \mathrm{c} 17$ lyase, and $17 \beta-\mathrm{HSD}$, are essential for the biosynthesis of testosterone in Leydig cells. We investigated whether PCB exerts direct inhibitory effects on the testosterone-synthesizing enzymes of Leydig cells. The first and rate-limiting enzymatic step in the biosynthesis of steroid hormones is the conversion of cholesterol to pregnenolone by cytochrome $\mathrm{P}_{450}$ scc (Payne \& Hales 2004). In this study, we measured cytochrome $\mathrm{P}_{450} \mathrm{scc}$ activity in the Leydig cells in vitro after 24-h PCB exposure in basal and LH-stimulated conditions. The $\mathrm{P}_{450} \mathrm{scc}$ activity was significantly diminished in PCBexposed Leydig cells in a dose-dependent manner under basal and LH-stimulated conditions. These results suggest that PCB directly downregulates the P450scc activity. RT-PCR analysis suggests that the loss of activity is due to reduced expression of this enzyme in PCB-exposed Leydig cells. In this regard, Murono et al. (2001) have reported that the cultured adult rat Leydig cells exposed to octylphenol could inhibit both cholesterol side-chain cleavage and $3 \beta-\mathrm{HSD}$ activities. In interstitial cells from adult rats, a mixture of PCBs was also
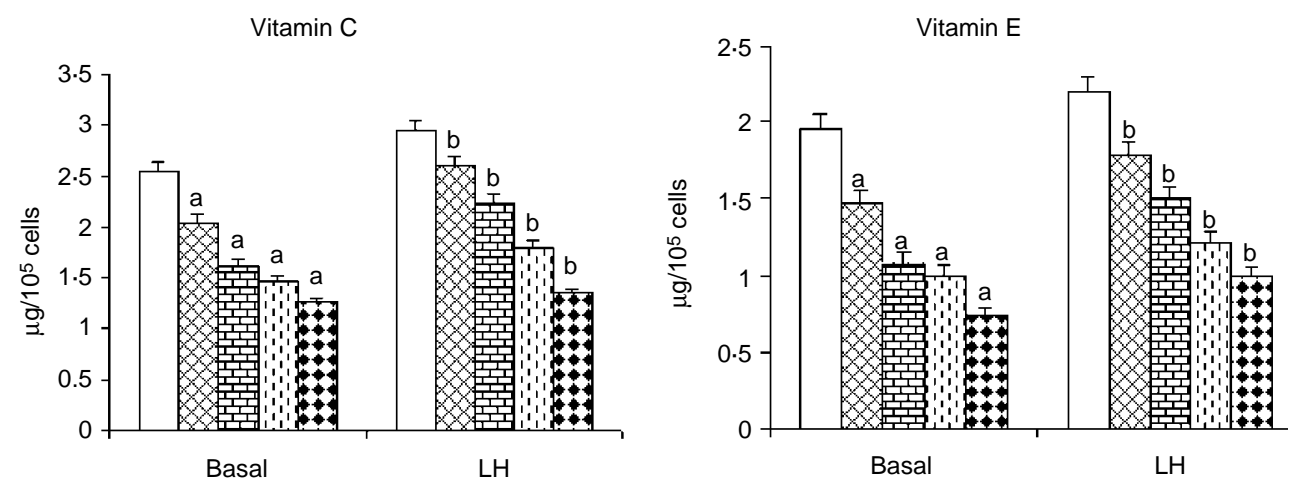

$$
\square \text { Control } 10^{-10} \mathrm{M} \quad 10^{-9} \mathrm{M} \quad 0^{-7} \mathrm{M}
$$

Figure 7 Dose-dependent effects of PCB (Aroclor 1254) on basal and LH-stimulated nonenzymatic antioxidants of Leydig cells in vitro. Each bar denotes mean \pm S.E.M of three independent experiments carried out in duplicates. Significance at $P<0.05 ; a$, compared with basal; $b$, compared with LH-stimulated. 

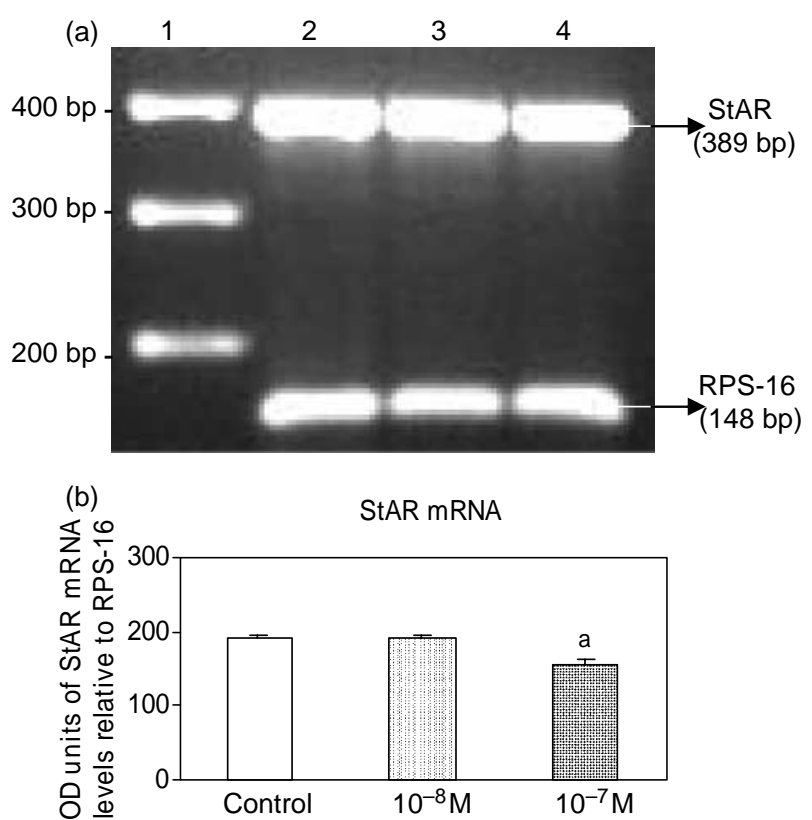

Figure 8 RT-PCR analysis of StAR protein mRNA expression in primary Leydig cells treated with Aroclor 1254 for $24 \mathrm{~h}$. The total RNA isolated from Leydig cells was reverse-transcribed and the cDNA obtained was subjected to PCR (a). Lane 1, DNA molecular marker; lane 2, control (vehicle); lane 3, Aroclor $125410^{-8} \mathrm{M}$; and Lane 4, Aroclor $125410^{-7} \mathrm{M}$ treatment. (b) The intensity of the signals was quantified by densitometry and normalized to that of RPS 16. The data provided are means \pm S.E.M. from three separate experiments. a, compared with control.

reported to inhibit hCG-stimulated or progesterone-supported testosterone production suggesting that $\mathrm{P}_{450} \mathrm{c} 17$ lyase activity was inhibited by PCBs (Andric et al. 2000). Furthermore, when newborn mouse testes were cultured with $\mathrm{PCB}, \mathrm{P}_{450} \mathrm{scc}$ mRNA expression was significantly downregulated (Fukuzawa et al. 2003). In the present study, Leydig cellular $3 \beta-$ HSD and $17 \beta-$ HSD activities were reduced in the PCB-exposed Leydig cells in a dosedependent manner under basal and LH-stimulated conditions suggesting defective function of Leydig cells. We also measured the expression of the $3 \beta-H S D$ and $17 \beta-H S D$ mRNAs, which showed a significant reduction in PCBexposed Leydig cells. The primer sequences used for amplification of $3 \beta-$ HSD and $17 \beta-$ HSD were derived from those of $3 \beta-H S D$ type I and $17 \beta-H S D$ type III respectively, which are the most predominant HSD isoforms in the testis (Baker et al. 1997, 1999). The decreased mRNA levels in PCB-exposed Leydig cells were also accompanied by reduced activities of steroidogenic enzymes suggesting the possible direct inhibitory effects of PCB on steroidogenic enzymes gene expression.

ROS can be produced in Leydig cells through the mitochondrial respiration (Chen et al. 2001) as well as cytochrome $\mathrm{P}_{450}$ enzymes of the steroidogenic pathway (Homsby 1989, Peltola et al. 1996). ROS can damage critical
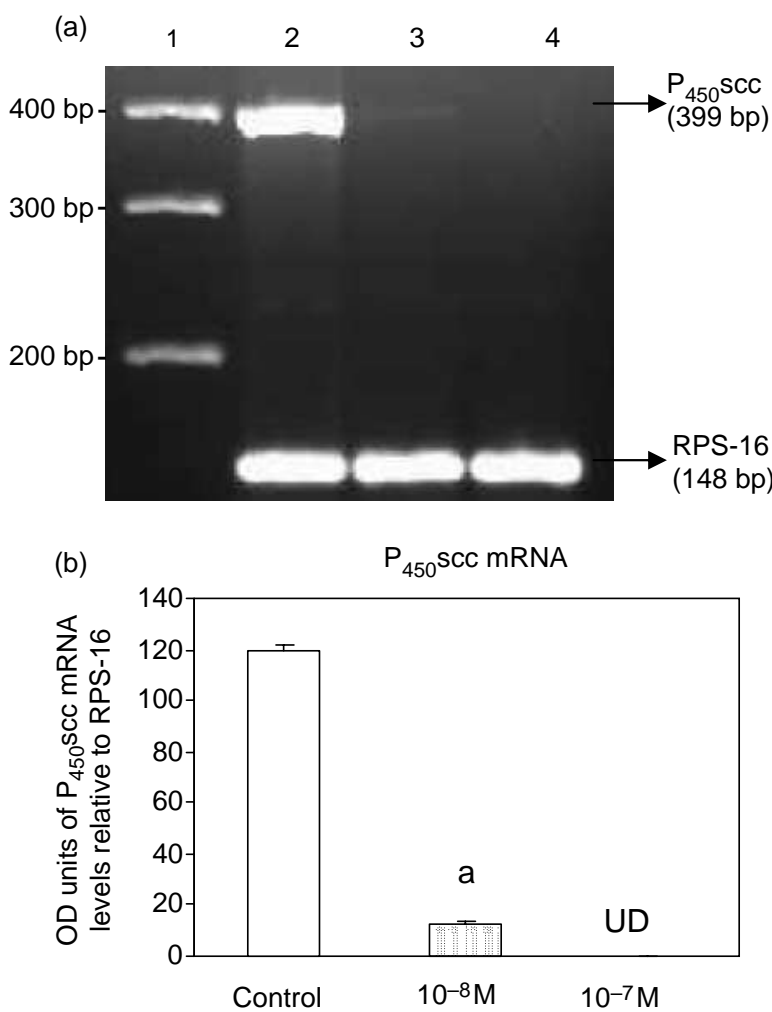

Figure 9 RT-PCR analysis of cytochrome $\mathrm{P}_{450} \mathrm{SCC}$ mRNA expression in Leydig cells treated with Aroclor 1254 for $24 \mathrm{~h}$. The total RNA isolated from Leydig cells was reverse transcribed and CDNA obtained was subjected to PCR (a). Lane 1, DNA molecular marker; lane 2, control (vehicle); lane 3, Aroclor 1254 $10^{-8} \mathrm{M}$; and lane 4, Aroclor $125410^{-7} \mathrm{M}$ treatment. (b) The intensity of the signals was quantified by densitometry and normalized to that of RPS 16 . The data provided are means \pm s.E.M. from three separate experiments. a, compared with control. UD, undetected.

components of the steroidogenic pathway in Leydig cells, including StAR protein (Diemer et al. 2003) and cytochrome $\mathrm{P}_{450}$ enzymes (Georgiou et al. 1987). Leydig tumor and luteal cells exposed to $\mathrm{H}_{2} \mathrm{O}_{2}$ showed impaired steroidogenesis due to defective cholesterol transport into mitochondria or its conversion to pregnenolone (Stocco et al. 1993, Musicki et al. 1994). We have also demonstrated that adult rats exposed to PCB may enhance ROS and LPO in Leydig cells. In addition, the activities of Leydig cellular steroidogenic and antioxidant enzymes were markedly reduced. However, simultaneous administration of vitamins $\mathrm{C}$ and $\mathrm{E}$ inhibits the ROS and LPO levels, which is accompanied by normal steroidogenic and antioxidant enzyme activities. In view of these findings, it is proposed that an increase in free radical formation results in the inhibition of steroidogenic enzymes and antioxidant defense system during exposure to PCB (Murugesan et al. $2005 b, c)$. Hydrogen peroxide can also act directly on rat Leydig cells to decrease the basal and hCG-stimulated testosterone production by inhibiting StAR protein expression and $\mathrm{P}_{450} \mathrm{scc}$ activity (Tsai et al. 2003). In the 


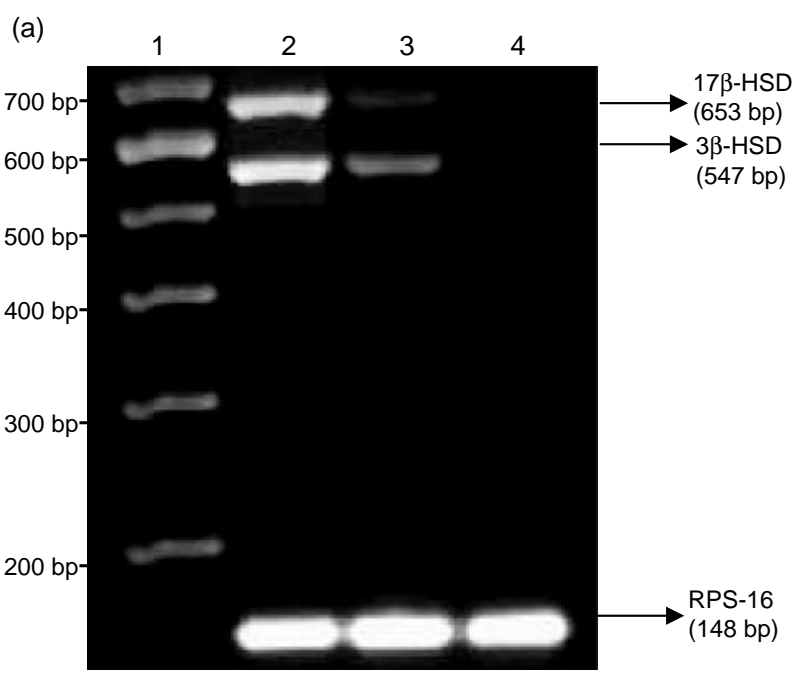

(b)

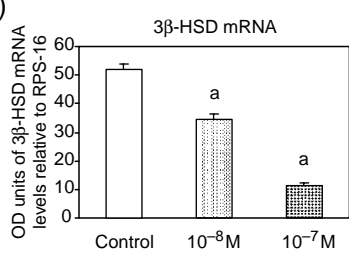

(c)

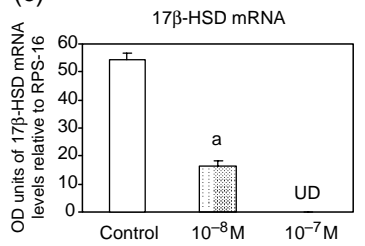

Figure 10 Co-amplification of $3 \beta-H S D$ and $17 \beta-H S D$ mRNAs expression by RT-PCR in Leydig cells treated with Aroclor 1254 for $24 \mathrm{~h}$. The total RNA isolated from Leydig cells was reverse transcribed and cDNA obtained was subjected to PCR (a). Lane 1, DNA molecular marker; lane 2, control (vehicle); lane 3, Aroclor $125410^{-8} \mathrm{M}$; and lane 4, Aroclor $125410^{-7} \mathrm{M}$ treatment. (b and c) The intensity of the signals was quantified by densitometry and normalized to that of RPS 16 . The data provided are means \pm S.E.M. from three separate experiments. a, compared with control; UD, undetected.

present study, decreased basal and LH-stimulated testosterone production was accompanied by an elevated level of hydrogen peroxide in PCB-exposed Leydig cells. In addition, the StAR protein mRNA level was decreased after PCB exposure. Several lines of evidence indicate that the interaction between the testicular antioxidants and the steroidogenic enzymes is complex and physiologically relevant (Murugesan et al. $2005 a, b, c)$. Free radicals react with lipids and cause peroxidative changes that result in enhanced lipid peroxidation. The enzymatic and nonenzymatic antioxidants are the natural defense systems against free radical-mediated tissue damage in several organs including the testis. The observed decreased activities of enzymatic antioxidants in PCB-exposed Leydig cells might have increased ROS and LPO production. These data suggest that the PCB-induced oxidative stress and elevated free radical generation may cause excessive oxidative damage to cellular membranes and possibly affect the functional integrity and capacity of mitochondria-associated steroidogenic machinery and/or accessory proteins involved in the cholesterol transport to the mitochondria. Our data also indicate that the increased free radical generation and the associated oxidative damage are at least partially due to the functional imbalance of enzymatic and nonenzymatic antioxidants defence system.

SOD is involved in the dismutation of the superoxide anion to hydrogen peroxide and oxygen. The decreased activity of SOD, observed in the present study, indicates either reduced synthesis of enzyme or elevated degradation or inactivation of the enzyme during Aroclor 1254 exposure. Earlier studies from our laboratory also demonstrated that adult rats exposed to Aroclor 1254 showed significant decrease in Leydig cellular SOD activity. However, simultaneous administration of either vitamin $\mathrm{C}$ or E maintained the SOD activity (Murugesan et al. $2005 b, c)$. CAT and GPx have been shown to be responsible for the detoxification of $\mathrm{H}_{2} \mathrm{O}_{2}$ (Cheng et al. 1981). In the present study, decreased activities of CAT and GPx in Aroclor 1254exposed Leydig cells under basal and LH-stimulated conditions may be attributed to ineffective scavenging of $\mathrm{H}_{2} \mathrm{O}_{2}$ thus leading to increased $\mathrm{H}_{2} \mathrm{O}_{2}$ noticed in Aroclor 1254-exposed Leydig cells. Furthermore, catalase is exclusively present in Leydig cell peroxisomes (Mendis-Handagama et al. 1990a,b). In addition, Leydig cell peroxisomes participate in the intracellular cholesterol trafficking and delivery into mitochondria during LH-stimulated steroidogenesis in adult rat (Mendis-Handagama 2000). In the present study, reduced catalase levels in Leydig cells of PCB-treated rats suggest that these cells have reduced amount/volumes of peroxisomes. GPx is present mainly in the cytosol and has several isozymes in plasma, plasma membrane, and mitochondria. These enzymes scavenge hydrogen peroxide to protect proteins and lipids. GST detoxifies a broad range of electrophilic compounds and protects against the lipid peroxidation of membranes and DNA-damage. The decreased activities of GR and $\gamma \mathrm{GT}$ in the present study suggest the increased oxidative stress in Aroclor 1254-exposed Leydig cells.

The highest concentrations of ascorbic acid occur in the pituitary, adrenal gland, and gonads (Chinoy 1972, Das et al. 1993). Ascorbic acid is required for collagen synthesis and its role in steroid and peptide hormone production. Its ability to protect cells from free radicals is also well recognized (Tsuji et al. 1989, Goralczyk et al. 1992). PCBs can alter ascorbic acid metabolism and enhance its urinary excretion (Mochizuki et al. 2000). A previous study from our laboratory revealed that the decreased serum testosterone and estradiol levels in Aroclor 1254-treated rats were accompanied by decreased testicular ascorbic acid concentration (Murugesan et al. 2005a). Ascorbic acid can prevent LPO in Sertoli and Leydig cells of Aroclor 1254exposed rat (Senthil kumar et al. 2004, Murugesan et al. 2005c). In the present study, the decreased ascorbic acid content in Aroclor 1254-exposed Leydig cells may contribute to increased levels of LPO. Vitamin E is an important antioxidant, residing mainly in cell membranes. It is thought to interrupt the chain reactions involved in lipid peroxidation and to scavenge ROS generated during univalent reduction of molecular oxygen (Palamanda \& Kehrer 1993). A recent finding shows that PCB 
induces the oxidative stress through decreased Leydig cellular vitamin $\mathrm{E}$ content in adult rats (Murugesan et al. 2005c). In the present study, Leydig cellular vitamin E content was significantly reduced in a dose-dependent manner due to Aroclor 1254 exposure under basal and LH-stimulated conditions. Therefore, it is suggested that the increased lipid peroxidation in Aroclor 1254-exposed Leydig cells may be in part the result of diminished vitamin $\mathrm{E}$ content.

It is concluded from the present study that PCB (Aroclor 1254) has direct adverse effects on Leydig cellular StAR protein and steroidogenic enzymes gene expression, LH receptors, enzymatic, and nonenzymatic antioxidants under basal and LH-stimulated conditions.

\section{Acknowledgements}

Financial assistance from the Indian Council of Medical Research (ICMR), New Delhi in the form of a Senior Research Fellowship (SRF) to Mr P Murugesan is gratefully acknowledged. Award No. 3/1/2/5(Env)/2003-NCD-I dated 22-10-2003. The authors wish to thank Dr M P Hardy, Population Council, New York, USA and Dr Benson Akingbemi, Auburn University, AL, USA for their valuable suggestions. The authors declare that there is no conflict of interest that would prejudice the impartiality of this scientific work.

\section{References}

Ahmad SU, Tariq S, Jalali S \& Ahmad MM 2003 Environmental pollutant Aroclor 1242 (PCB) disrupts reproduction in adult male rhesus monkeys (Macaca mulatta). Environmental Research 93 272-278.

Akingbemi BT, Sottas CM, Koulova AI, Klinefelter GR \& Hardy MP 2004 Inhibition of testicular steroidogenesis by xenoestrogens bisphenol A is associated with reduced pituitary luteinizing hormone secretion and decreased steroidogenic enzymes gene expression in rat Leydig cells. Endocrinology 145 592-603.

Aldred LF \& Cooke BA 1983 The effect of cell damage on the density and steroidogenic capacity of rat testis Leydig cells, using an NADH exclusion test for determination of viability. Journal of Steroid Biochemistry 18 411-414.

Andric SA, Kostic TS, Stojilkovic SS \& Kovacevic RZ 2000 Inhibition of rat testicular androgenesis by a polychlorinated biphenyl mixture Aroclor 1248. Biology of Reproduction 62 1882-1888.

Baker PJ, Sha JH \& O'Shaughnessy PJ 1997 Localisation and regulation of 17 beta-hydroxysteroid dehydrogenase type 3mRNA during development in the mouse testis. Molecular and Cellular Endocrinology 133 127-133.

Baker PJ, Sha JA, McBride MW, Peng L, Payne AH \& O’Shaughnessy PJ 1999 Expression of $3 \beta$-hydroxysteroid dehydrogenase type I and IV isoforms in the mouse testis during development. European Journal of Biochemistry $\mathbf{2 6 0}$ 911-916.

Bergmeyer MU 1974 Steroid dehydrogenase. In Methods of Enzymatic Analysis, pp 476-477. Ed. HU Bergmeyer. New York: Academic Press.

Bruss SP, Schuppe HC \& Schill WB 2004 The male reproductive system and its susceptibility to endocrine disrupting chemicals. Andrologia 36 337-345.

Burton GW, Cheeseman KH, Doba T, Ingold KU \& Slater TF 1983 Vitamin $\mathrm{E}$ as an antioxidant in vitro and in vivo. Ciba Foundation Symposium 101 4-18. Chen H, Cangello D, Benson S, Folmer J, Zhu H, Trush MA \& Zirkin BR 2001 Age-related increase in mitochondrial superoxide generation in the testosterone-producing cells of brown Norway rat testes: relationship to reduced steroidogenic function? Experimental Gerontology 36 1361-1373.
Cheng L, Kellogg EW III \& Packer L 1981 Photoinactivation of catalase. Photochemistry and Photobiology 34 125-129.

Cheng J, Fu JL \& Zhou ZC 2003 The inhibitory effects of manganese on steroidogenesis in rat primary Leydig cells by disrupting steroidogenic acute regulatory (StAR) protein expression. Toxicology 187 139-148.

Cheng J, Fu J \& Zhou Z 2005 The mechanism of manganese-induced inhibition of steroidogenesis in rat primary Leydig cells. Toxicology 211 1-11.

Chinoy NJ 1972 Ascorbic acid levels in mammalian tissues and its metabolic significance. Comparative Biochemistry Physiology A, Comparative Physiology 42 945-952.

Chow CK 2004 Biological functions and metabolic fate of vitamin E revisited. Journal of Biomedical Science 11 295-302.

Clark BJ, Wells J, King SR \& Stocco DM 1994 The purification, cloning, and expression of a novel luteinizing hormone-induced mitochondrial protein in MA-10 mouse Leydig tumor cells. Characterization of the steroidogenic acute regulatory protein (StAR). Journal of Biological Chemistry 269 28314-28322.

Cooke PS, Zhao YD \& Hansen LG 1996 Neonatal polychlorinated biphenyl treatment increases adult testis size and sperm production in the rat. Toxicology and Applied Pharmacology 136 112-117.

Das PC, Das KP, Bagchi H \& Dey CD 1993 Evalution of tissue ascorbic acid status in different hormonal states of female rat. Life Science 52 1493-1498.

Desai ID 1984 Vitamin E analysis methods for animal tissues. Methods in Enzymology 105 138-147.

Devasagayam TP \& Tarachand U 1987 Decreased lipid peroxidation in the rat kidney during gestation. Biochemical and Biophysical Research Communications $145134-138$.

Diemer T, Allen JA, Hales KH \& Hales DB 2003 Reactive oxygen disrupts Mitochondria in MA-10 tumor Leydig cells and inhibits steroidogenic acute regulatory (StAR) protein and steroidogenesis. Endocrinology 144 2882-2891.

Fukuzawa NH, Ohsako S, Nagano R, Sakaue M, Baba T, Aoki Y \& Tohyama C 2003 Effects of 3,3',4,4',5-pentachlorobiphenyl, a coplanar polychlorinated biphenyl congener, on cultured neonatal mouse testis. Toxicology In Vitro 17 259-269.

Fukuzawa NH, Ohsako S, Wu Q, Sakaue M, Fujii-Kuriyama Y, Baba T \& Tohyama C 2004 Testicular cytochrome P450scc and LHR as possible targets of 2,3,7,8-tetrachlorodibenzo-p-dioxin (TCDD) in the mouse. Molecular and Celluar Endocrinology 221 87-96.

Georgiou M, Prekins LM \& Payne AH 1987 Steroid synthesis dependent oxygen-mediated damage of mitochondrial and microsomal cytochrome P-450 enzymes in rat Leydig cell cultures. Endocrinology 121 1390-1399.

Goralczyk R, Moser UK, Matter U \& Weiser H 1992 Regulation of steroid hormone metabolism requires L-ascorbic acid. Annals of the New York Academy Sciences 669 349-351.

Gray LE, Ostby J, Marshalln R \& Andrew J 1993 Reproductive and thyroid effects of low level polychlorinated biphenyl (Aroclor 1254) exposure. Fundamental and Applied Toxicology 20 288-294.

Habert R, Lejeune H \& Saez JM 2001 Origin, differentiation and regulation of fetal and adult Leydig cells. Molecular and Cellular Endocrinology 179 $47-74$.

Habig WH, Pabst MJ \& Jakoby WB 1974 Glutathione-S-transferase. The first enzymatic step in mercapturic acid formation. Journal of Biological Chemistry $2497130-7139$

Halliwell B, Wasil M \& Grootveld M 1987 Biologically significant scavenging of the myeloperoxidase-derived oxidant hypochlorous acid by ascorbic acid. Implications for antioxidant protection in the inflamed rheumatoid joint. FEBS Letter 213 15-17.

Holland MK \& Storey BT 1981 Oxygen metabolism of mammalian spermatozoa. Generation of hydrogen peroxide by rabbit epididymal spermatozoa. Biochemical Journal 198 273-280.

Homsby PJ 1989 Steroid and xenobiotic effects on the adrenal cortex: mediation by oxidative and other mechanisms. Free Radical Biology and Medicine 6 103-115.

Kim IS, Ariyaratne HB \& Mendis-Handagama SMLC 2001 Effects of continuous and intermittent exposure of lactating mothers to Aroclor 1242 on testicular steroidogenic function in the adult male offspring. Tissue and Cell 33 169-177. 
Kimbrough RD 1995 Polychlorinated biphenyls (PCBs) and human health: an update. Critical Reviews in Toxicology 25 133-163.

Kovacevic R, Milorado VM, Teodorovic I \& Andric S 1995 Effect of PCBs on androgen production by suspension of adult rat Leydig cells in vitro. Journal of Steroid Biochemistry and Molecular Biology 2 595-597.

Krishnamoorthy G, Murugesan P, Muthuvel R, Gunadharini N, Vijayababu MR, Arunkumar A, Venkataraman P, Aruldhas MM \& Arunakaran J 2005 Effect of Aroclor 1254 on Sertoli cellular antioxidant system, androgen binding protein and lactate in adult rat in vitro. Toxicology 212 195-205.

Lowry OH, Rosebrough NJ, Farr AL \& Randall RJ 1951 Protein measurement with the Folin phenol reagent. Journal of Biological Chemistry $193265-275$.

Marklund S \& Marklund G 1974 Involvement of the superoxide anion radical in the autooxidation of pyrogallol and a convenient assay for superoxide dismutase. European Journal of Biochemistry 47 469-474.

Massaad C, Entezami F, Massade L, Benahmed M, Olivennes F, Barouki R \& Hamamah S 2002 How can chemical compounds alter human fertility? European Journal of Obstetrics and Gynecology Reproductive Biology 100 127-137.

Mendis-Handagama SMLC 2000 Peroxisomes and intracellular cholesterol trafficking in adult rat Leydig cells following luteinizing hormone stimulation. Tissue Cell 32 102-106.

Mendis-Handagama SMLC, Watkins PA, Gelber SJ, Scallen TJ, Zirkin BR \& Ewing LL 1990 a Luteinizing hormone causes rapid and transient changes in rat Leydig cell peroxisome volume and intraperoxisomal sterol carrier protein-2 content. Endocrinology 127 2947-2954.

Mendis-Handagama SMLC, Zirkin BR, Scallen TJ \& Ewing LL $1990 \mathrm{~b}$ Studies on peroxisomes of the adult rat Leydig cell. International Journal of Andrology 11 270-278.

Mochizuki H, Oda H \& Yokogoshi H 2000 Dietary taurine alters ascorbic acid metabolism in rats fed diets containing polychlorinated biphenyls. Journal of Nutrition 130 873-876.

Murono EP, Derk RC \& Leon JH 2001 Differential effects of octylphenol, $17 \beta$-estradiol, endosulfan, or bisphenol A on the steroidogenic competence of cultured adult rat Leydig cells. Reproductive Toxicology 15 551-560.

Murugesan P, Senthil kumar J, Balasubramanian K, Aruldhas MM \& Arunakaran J 2005a Impact of polychlorinated biphenyl Aroclor 1254 on testicular antioxidant system in adult rats. Human and Experimental Toxicology 24 61-66.

Murugesan P, Kanagaraj P, Yuvaraj S, Balasubramanian K, Aruldhas MM \& Arunakaran J $2005 b$ The inhibitory effects of polychlorinated biphenyl (Aroclor 1254) on Leydig cell LH receptors, steroidogenic enzymes, and antioxidant enzymes in adult rats. Reproductive Toxicology 20 117-126.

Murugesan P, Muthusamy T, Balasubramanian K \& Arunakaran J 2005c Studies on the protective role of vitamin $\mathrm{C}$ and $\mathrm{E}$ against polychlorinated biphenyl (Aroclor 1254) - induced oxidative damage in Leydig cells. Free Radical Research 39 1259-1272.

Musicki B, Aten RF \& Behrman HR 1994 Inhibition of protein synthesis and hormone-sensitive steroidogenesis in response to hydrogen peroxide in rat luteal cells. Endocrinology 134 588-595.

Muthuvel R, Venkataraman P, Krishnamoorthy G, Gunadharini DN, Kanagaraj P, Jone Stanley A, Srinivasan N, Balasubramanian K, Aruldhas MM \& Arunakaran J 2006 Antioxidant effect of ascorbic acid on PCB (Aroclor 1254) induced oxidative stress in hypothalamus of albino rats. Clinica Chimica Acta 365 297-303.

Nessel CS \& Gallo MA 1994 Dioxins and related compounds. In Environmental Toxicants: Human Exposure and their Health Effects, pp 163-182. Ed. M Lippmann. New York: Van Nostrand Reinhold.

Omaye ST, Turnbull JD \& Sauberlich HE 1979 Selected methods for the determination of ascorbic acid in animal cells, tissues and fluids. Methods in Enzymology 62 3-11.

Orlowski M \& Meister A 1965 Isolation of $\gamma$-glutamyl transpeptidase from hog kidney. Journal of Biological Chemistry 240 338-347.

Palamanda JR \& Kehrer JP 1993 Involvement of vitamin E and protein thiols in the inhibition of microsomal lipid peroxidation by glutathione. Lipids $\mathbf{2 8}$ 427-431.
Payne AH \& Hales DB 2004 Overview of steroidogenic enzymes in the pathway from cholesterol to active steroid hormones. Endocrine Reviews 25 947-970.

Peltola V, Huhtaniemi I, Metsa-Ketela T \& Ahotupa M 1996 Induction of lipid peroxidation during steroidogenesis in the rat testis. Endocrinology 137 105-112.

Puntarulo S \& Cederbaum AI 1988 Effect of oxygen concentration on microsomal oxidation of ethanol and generation of oxygen radicals. Biochemical Journal 251 787-794.

Quinn PG \& Payne AH 1985 Steroid product-induced oxygen mediated damage of microsomal cytochrome P-450 enzymes in Leydig cell cultures. Journal of Biological Chemistry $2602092-2099$.

Rigaudiere N, Loubassou S, Grizard G \& Boucher D 1988 Characterization of insulin binding and comparative action of insulin and insulin-like growth factor I on purified Leydig cells from the adult rat. International Journal of Andrology 11 165-178.

Rotruck JT, Pope AL, Ganther HE, Swanson AB, Hafeman DG \& Hoekstra WG 1973 Selenium: biochemical role as a component of glutathione peroxidase. Science 179 588-590.

Rozati R, Reddy PP, Reddanna P \& Mujtaba R 2002 Role of environmental estrogens in the deterioration of male factor fertility. Fertility and Sterility $\mathbf{7 8}$ 1187-1194.

Safe SH 1995 Modulation of gene expression and endocrine response pathways by $2,3,7,8$-tetrachlorodibenzo-p-dioxin and related compounds. Pharmacology and Therapeutics 67 247-281.

Sakaue M, Ishimura R, Kurosawa S, Fukuzawa NH, Kurohmaru M, Hayashi Y, Tohyama C \& Ohsako S 2002 Administration of estradiol-3-benzoate down-regulates the expression of testicular steroidogenic enzyme genes for testosterone production in the adult rat. Journal of Veterinary Medical Science/Japanese Society of Veterinary Science 64 107-113.

Senthil kumar J, Banudevi S, Sharmila M, Murugesan P, Srinivasan N, Balasubramanian K, Aruldhas MM \& Arunakaran J 2004 Effects of vitamin $\mathrm{C}$ and $\mathrm{E}$ on PCB (Aroclor 1254) induced oxidative stress, androgen binding protein and lactate in rat Sertoli cells. Reproductive Toxicology 19 201-208.

Sinha AK 1972 Colorimetric assay of catalase. Analytical Biochemistry 47 389-394.

Staal GE, Visser J \& Veeger C 1969 Purification and properties of glutathione reductase of human erythrocytes. Biochimica et Biophysica Acta 185 39-48.

Stocco DM 2001 StAR protein and the regulation of steroid hormone biosynthesis. Annual Reviews of Physiology 63 193-213.

Stocco DM, Wells J \& Clark BJ 1993 The effects of hydrogen peroxide on steroidogenesis in mouse Leydig tumor cells. Endocrinology 133 2827-2832.

Sufi SB, Donaldson A \& Fejjcoate SL 1986 Testosterone and estradiol assay. In: World Health Organization Collaborating Centre for Research and Reference Services in the Immunoassay of Hormones in Human Reproduction. 10th edn, pp 57-85. Geneva: WHO.

Thorell JI \& Johansson BG 1971 Enzymatic iodination of polypeptides with 125I to high specific activity. Biochimica et Biophysica Acta 363-369.

Tsai SO, Lu CC, Lin CS \& Wang PS 2003 Antisteroidogenic action of hydrogen peroxide on rat Leydig cells. Journal of Cellular Biochemistry 90 $1276-1286$.

Tsuji M, Ito Y, Terada N \& Mori H 1989 Ovarian aromatase activity in scorbutic mutant rats unable to synthesis ascorbic acid. Act Endocrinologica 121 595-602.

Vidaeff AC \& Sever LE 2005 In utero exposure to environmental estrogens and male reproductive health: a systematic review of biological and epidemiologic evidence. Reproductive Toxicology 20 5-20.

Walsh LP \& Stocco DM 2000 Effects of lindane on steroidogenesis and steroidogenic acute regulatory protein expression. Biology of Reproduction $\mathbf{6 3}$ 1024-1033.

Walsh LP, McCormick C, Martin C \& Stocco DM 2000 Roundup inhibits steroidogenesis by disrupting steroidogenic acute regulatory (StAR) protein expression. Environmental Health Perspectives 108 769-776.

\section{Received in final form 29 September 2006} Accepted 25 October 2006 